14. Available at: https://www.researchgate.net/ publication/299376618_Issues_and_Trends_of_ International_Students_in_the_United_States (Accessed 25 Oct. 2020). [in English].

7. Global Flow of Tertiary-Level Students. UNESCO. Available at: http://uis.unesco.org/en/uisstudent-flow (Accessed 26 Mar. 2020). [in English].

8. John F. Kennedy: 1961: containing the public messages, speeches, and statements of the president, January 20 to December 31, 1961. Washington : Office of the Federal Register, National Archives and Records Service, General Services Administration, 908 p. [in English].

9. Legislation on foreign relations through 2005 (Volume I-A). U. S. House of Representatives \& U.S. Senate. (2006). Washington DC: U.S. Government Printing Office, pp. 420-542. [in English].
10. Mutual Education and Cultural Exchange Program. United States Code. Title 22. (2002). Washington, DC: Office of the Law Revision Coundel of the U.S. House of Representatives, 1526 p. [in English].

11. Peace Corps fact sheet 2019. Available at: http://files.peacecorps.gov/multimedia/pdf/about/ pc_facts.pdf(Accessed 13 Feb. 2021). [in English].

12. Read, G. (1966). The International Education Act of 1966. The Phi Delta Kappan, 47, 8, pp. 406409. [in English].

13. Sarkodie-Mensah, K. (1998). International students in the US: Trends, cultural adjustments, and solutions for a better experience. Journal of Education for Library and Information Science, 39(3), pp. 214-222. [in English].

14. Spilimbergo, A. (2006). Democracy and foreign education. The American Economic Review, 99, 1, pp. 528-543. [in English].

Стаття надійшла до редакції 20.04.2021

УДК 378.147.016:640

DOI:

Юрій Безрученков, кандидат педагогічних наук, доцент кафедри туризму, готельної і ресторанної справи Луганського начіонального університету імені Тараса Шевченка

\title{
ПЕДАГОГІЧНИЙ КОНТРОЛЬ В СИСТЕМІ ЦИФРОВОЇ ОСВІТИ
}

Під час електронного освітнього процесу контроль навчання здобувачів освіти відіграє одну з ключових ролей, педагогічний контроль повинен здійснюватися при використанні різних контрольних заходів, за допомогою різноманітних иляхів оцінювання як індивідуальних, так і групових завдань з використанням неоднакових типів завдань. У статті проводиться аналіз підходів до контролю знань в процесі ицифрової освіти. Розглядається сутність застосування закладом вищьої освіти єдиної LMS системи засобу для здійснення комунікачї $і$ контролю між здобувачами освіти та викладачами.

Ключові слова: електронна освіта; педагогічний контроль в цифрровій освіті; реалізачія циифрового навчання в Україні; контроль знань в дистанційній освіті; підходи до контролю знань.

Jim. 8.

Yuriy Bezruchenkov, Ph.D.(Pedagogy), Associate Professor of the Tourism, Hotel and Restaurant Business Department Luhansk Taras Shevchenko National University

\section{PEDAGOGICAL CONTROL IN THE PROCESS OF DIGITAL EDUCATION}

The implementation of pedagogical control over the educational process in the context of education in the digital space is a very important element of the educational process of higher education institutions. The transition to e-education involves the activation of the teacher both in providing the applicant with a diverse, heterogeneous type of educational material, and in the implementation of pedagogical control using various control measures. This applies, inter alia, to students who perform tasks independently, the purpose of which is not only to achieve high knowledge in learning, but also to acquire new skills such as self-control. To do this, the whole process of learning and cognitive activity must be organized accordingly, different from the standard.

The article analyzes the approaches to knowledge control in the process of digital education. The essence of the concept of pedagogical control in general and the peculiarities of the use of educational systems in higher educational institutions as a means of communication and control between students and teachers are considered. The author notes that e-learning involves the control of students' knowledge through appropriate means of communication. Such means of communication can be built into learning management systems (LMS), e-mail, some messengers (Viber, Telegram), programs for video conferencing (MS Teams, ZOOM, Google Meet, Skype), forums, chats. The author emphasizes that higher education institutions in Ukraine are recommended to use a single 
learning management system, the system as a means of communication between students and teachers, and during distance learning teachers should apply various measures to control the learning process: both current and periodic. The very control measures to be applied in the digital education system, the analysis of which is carried out in the article, must meet such requirements as: the need to obtain permission to obtain information and communication tools for e-education; the ability to determine the time of both start and end of access, as well as the duration of tasks; ensuring the objectivity of the criteria used to verify the results of tasks with the involvement of automated knowledge assessment in this process; high variability in the formation of tasks to control the use of algorithms aimed at implementing a random selection of questions.

Keywords: e-education; pedagogical control in digital education; implementation of digital learning in Ukraine; control of knowledge in distance education; approaches to knowledge control.

П остановка проблеми. На сьогоднішньому етапі соціальноекономічному розвитку суспільства вимоги до фахівців будь-якого рівня є досить значними. Це зумовило необхідність суттєвого вдосконалення якості освітнього процесу у вищій школі, для чого потрібні відповідні засоби, що відрізняються своєю ефективністю. Для здійснення якісної підготовки здобувачів освіти до виконання ними професійної діяльності у майбутньому та під час освітнього процесу необхідно проводити діагностику відповідності підготовки випускників закладів вищої освіти тим вимогам, які висуваються стосовно них у державному освітньому стандарті. У такий спосіб можна швидко виявити наявні прогалини та здійснити корекцію проблем у ході здійснення освітнього процесу.

Дидактика вищої школи протягом багатьох років вивчає проблематику контролю теоретичних знань, а також практичних умінь та навичок здобувачів освіти. Цій темі приділили увагу в своїх роботах такі вчені: А. Алексюк, В. Приходько, Ю. Бабанський, В. Вікторов, В. Безпалько, М. Махмутов, С. Вітвицька, А. Кузьмінський, І. Булах, М. Фіцула, Л. Добровська, Е. Лузік, та інші. Попри це, наразі спостерігається значне підвищення вимог до якості підготовчого процесу фахівців. Задля цього потрібно здійснювати подальший пошук новітніх методик та прийомів як у традиційній так і цифровій освіті, котрі допомогли б віднайти інноваційні форми контролю здобувачів освіти.

Мета статті - аналіз підходів до контролю знань у системі цифрової освіти.

Виклад основного матеріалу. Для значного підвищення ефективності освітнього процесу в тих умовах, які наразі склалися в Україні, одним із найбільш оптимальних засобів $є$ розробка та впровадження стимулюючої системи здійснення контролю за навчальною діяльністю здобувачів освіти.

Здобуття освіти - це один з основних типів діяльності будь-якої люди, метою якого $є$ засвоєння теоретичних знань за допомогою розв'язання тих чи тих навчальних задач. Завдяки системній та постійній реалізації освітньої діяльності вдається інтенсивно розвивати у іiі суб'єктів теоретичну свідомість та мислення. Серед основних складових останнього варто відзначити не тільки аналіз, абстракції та узагальнення, але й планування та рефлексії. Одним 3 головних завдань сучасної системи освіти є створення умов та запровадження технології для виявлення і розвитку здібностей особистості [2].

До передумов здійснення освітнього процесу можна віднести мету, здатну стимулювати здобувача освіти до цілеспрямованої роботи в рамках навчально-пізнавальної діяльності, мотивацію до набуття професії у майбутньому, соціальну та морально-психічну готовність до виконання професійних обов'язків, самостійність i активність у процесі отримання й засвоєння знань, а також зосередженість на процесі опанування відповідного рівня майстерності у профільних предметах [8]. Здійснювати освітню діяльність без контролю практично неможливо. При цьому, дослідивши наявну наукову літературу, можна зробити висновок, що наразі немає чіткого консенсусу серед науковців про те, як саме повинен трактуватися термін “контроль”. В одній зі своїх робіт А. Кузьмінський відзначив, що контроль варто визначати як важливий компонент системи освітнього процесу, провадження котрого може здійснюватись у декількох формах, спрямованих на визначення рівня знань, навичок та вмінь, отриманих здобувачами освіти в навчальному процесі [3]. На думку В. Приходько, контроль в контексті педагогічного процесу у ЗВО варто розуміти як спосіб педагогічного керівництва навчально-пізнавальною діяльністю здобувачів освіти, в ході якого виконується поетапне періодичне оцінювання, а також корекція підготовки спеціалістів як щодо засвоєння знань, умінь і навичок, так і виховання здобувачів освіти [4]. Л. Романишина запропонувала своє визначення контролю. 3 їі точки зору, він $\epsilon$ діяльністю, що направлена на виявлення рівнів навченості здобувачів освіти задля приведення отриманих ними результатів до професійного рівня. Під рівнем навченості в цьому плані варто 


\section{ПЕДАГОГІЧНИЙ КОНТРОЛЬ В СИСТЕМІ ЦИФРОВОЇ ОСВІТИ}

розуміти етапи поступового підвищення якості фахової підготовки у процесі освоєння тих чи тих дисциплін. До того ж контроль знань у такому випадку сприяє здійсненню розвитку психічних процесів будь-якої особистості. До них належать пам'ять, мислення, пізнавальна активність, мова, мовленнєве спілкування, а також навички систематичної та самостійної праці [5].

Якщо розглянути умови сучасної школи вищої освіти України, можна зрозуміти, що наявних трактувань контролю освітнього процесу наразі недостатньо. Визначення цього терміна має бути значно ширшим. Це зумовлено тим, що він насправді $є$ складовим елементом системи підготовки фахівців різних сфер діяльності, через що охоплює три напрями: контроль науковометодичної роботи, контроль навчальних досягнень, а також контроль якості навчання. До контролю навчальних процесів слід відносити не тільки предмет знання, а й уміння та отримані здобувачами освіти навички. Якщо контроль навчальних досягнень направлений безпосередньо на предмет знання, а також уміння та навички, надбані здобувачем освіти, то контроль якості навчання припускає потребу визначити рівень можливість підвищення професійної майстерності безпосередньо самих педагогів. Одночасне застосування обох методів допомагає здійснити оцінку ступеню досягнення поставлених перед навчанням цілей. До того ж у такий спосіб виявляються наявні проблеми, що виникають у здобувачів освіти в процесі навчання. Контроль стимулює до самостійної роботи та допомагає оцінити ступінь професіоналізму кожного викладача. Обидва напрями його здійснення сприяють отриманню інформації, що може бути потрібною для удосконалення навчальної, наукової чи методичної роботи [6]. Якщо говорити про контроль в рамках одного 3 елементів дидактичного процесу, він виконує декілька функцій. Серед них варто виділити освітню, діагностичну, виховну, вимірювальну, оцінювальну, прогностично-методичну та керівну. Відповідно до традиційної педагогічної практики, науковці визначили такі види контролю за його призначенням та характером: попередній i поточний. Обидва вони можуть використовуватися у дистанційному навчальному процесі. Основним принципом електронної освіти є встановлення інтерактивного спілкування, що має здійснюватися між здобувачем освіти та викладачем. При цьому відсутня потреба в забезпеченні їхньої безпосередньої участі. Це допомагає самостійному засвоєнню здобувачем освіти матеріалу та отриманню ним навичок відповідно до вибраного курсу [1].
Електронна освіта передбачає здійснення контролю знань здобувачів освіти за допомогою відповідних засобів комунікації. Вони можуть бути вбудовані в системи управління навчання (LMS), e-mail, деякі месенджери (Viber, Telegram та ін.), програми для відеоконференцій (MS Teams, ZOOM, Google Meet, Skype та ін.), форуми, чати тощо.

Закладам вищої освіти рекомендується застосування єдиної LMS системи засобу для здійснення комунікації між здобувачами освіти та викладачами. Під час проведення навчання у дистанційному режимі варто користуватися різними контрольними заходами освітнього процесу як поточними, так і періодичними. При цьому вони повинні відповідати деяким вимогам, таким як:

- необхідність в авторизації задля отримання інформаційно-комунікаційних інструментів організації електронної освіти;

- можливість визначення часу як початку, так і закінчення доступу, а також тривалості виконання поставлених завдань;

- забезпечення об'єктивності використаних критеріїв для здійснення перевірки результатів виконання завдань із залученням до цього процесу автоматизованих інструментів оцінювання знань;

- висока варіативність формування завдань для контролю з використання алгоритмів, направлених на здійснення випадкового вибору запитань [7].

Під час електронного освітнього процесу поточний контроль навчання здобувачів освіти повинен здійснюватися безпосередньо на дистанційних заняттях. Для цього передбачені певні шляхи оцінювання як індивідуальних, так і групових завдань, здійснюваних здобувачами освіти. Збільшення об'єктивності у таких випадках слід досягати завдяки використанню різних типів завдань, до яких належать такі:

- автоматизовані тести, призначені для стороннього контролю та самоконтролю навчальних досягнень;

- різнорівневі індивідуальні та групові завдання (звіти, презентації, проєкти, відеозаписи тощо) 3 передбаченим наданням відповідного зворотного зв'язку з метою повідомлення про результати перевірки навчальних досягнень по освітньому матеріалу, що вивчався до цього;

- оцінювання педагогом здійснення взаємодії та комунікації між здобувачем освіти в асинхронному і синхронному режимах за допомогою чату, форуму, опитування, анкетування тощо;

- взаємне оцінювання здобувачами освіти виконання наданих викладачем завдань один одного; 


- оцінювання педагогом отриманих результатів
виконання здобувачами освіти групових завдань,
що потребують використання глосаріїв, вікі, а
також спеціалізованих баз даних по конкретному
навчальному предмету;
- завдання, що потребують надання здобувачем
освіти розгорнутої, творчої відповіді (наприклад,
кейси);
- завдання, форма яких адаптована до
виконання засобами єдиної системи управління
навчанням LМS;
- додаткові інструменти.
У деяких випадках для якісного засвоєння
окремих тематичних розділів, модулів та
змістових частин конкретної дисципліни потрібно
використовувати дистанційні онлайн-курси,
проходження яких здійснюється на відповідних
платформах. Додаткові бали в таких ситуаціях
здобувачам освіти потрібно зараховувати при
наданні ними сертифікатів, що підтверджують
успішне проходження цього етапу освітнього
процесу.

До семестрового контролю результатів освітнього процесу здобувачів освіти можуть належати екзамени, захисти курсових робіт, звіти про проходження практики на підприємствах тощо. Цей етап оцінювання має можливість відбуватися у дистанційній формі. Для цього варто використовувати засоби LMS, а також додаткові інструменти - як синхронної, так і асинхронної комунікації. До них належать, у тому числі, і системи проведення відеоконференцій. Для того щоб акцентувати увагу здобувачів освіти на дійсно важливих темах, викладач має право зменшити обсяг матеріалу дисципліни, котрий буде виноситися на підсумковий контроль за рахунок тих тем, що не мають значної ваги в рамках вивчення конкретного предмету. Якщо застосовані заходи дають змогу повною мірою оцінити рівень набуття певних знань, передбачених дисципліною, педагог може виставити підсумкову оцінку за екзамен або ж залік за допомогою пропорційного перерахунку отриманих здобувачем освіти семестрових балів в підсумкову оцінку.

Екзаменаційна форма проведення семестрового контролю здійснюється за попередньо передбаченим розкладом екзаменаційної сесії. У такому разі необхідно забезпечити умови проведення ідентифікації особи, котра здобуває освіту. Мова йде передовсім про завдання, що виконуються в усній формі. На екзамен допускається винесення різних типів завдань, таких як:

- тестові запитання;
- типові та комплексні задачі;

- завдання, що потребують творчої відповіді та вмінь поєднувати здобуті знання з подальшим ïх застосуванням для розв'язання тих чи тих практичних завдань [7].

При укладанні письмових завдань необхідно приділити належну увагу їх якості. Їх слід сформулювати так, щоб здобувачам освіти потрібно було проявити творчі навички, передбачені програмою конкретної дисципліни. Варто передбачити неможливість копіювання здобувачами освіти відповідей з інших джерел.

Для проведення передекзаменаційних консультацій допускається застосування інструментів аудіо- чи відеоконференцій, що проводяться за чітко затвердженим розкладом. Під час цього заняття рекомендується проведення перевірки усіх технічних параметрів налаштування зв'язку зі здобувачами освіти 3 подальшим усуненням виявлених проблем. Спосіб проведення екзамену і його структурні етапи повинні визначатися на основі як технічних, так і комунікативних можливостей всіх суб'єктів освітнього процесу. Здобувачам освіти в такому разі варто налагодити надійний інтернет-зв'язок, можливість встановлення відповідного ПЗ, а у випадку надання усних відповідей - передбачити доступ до комп'ютера чи телефону з вбудованим або ж зовнішнім мікрофоном.

До екзаменаційного завдання допускається внесення таких завдань:

- тестові запитання, що в автоматичному режимі формуються індивідуально для кожного здобувача освіти за допомогою випадкового їх вибору із загальної бази й з перемішуванням запропонованих варіантів відповідей між собою (такі можливості доступні в більшості LMS, a також на спеціалізованих сервісах $з$ онлайнтестування: Moodle, Classmarker тощо);

- творчі завдання та експериментальні ситуації, для розв'язання яких здобувачам освіти необхідно застосовувати комплексні знання 3 конкретної дисципліни;

- набори практичних ситуацій, до яких належать стереотипні, діагностичні та евристичні завдання, що потребують від здобувачів освіти розв'язання професійних задач на робочому місці 3 оцінкою ступеню теоретичної та практичної готовності і рівнів компетентностей з навчальної дисципліни (такі ситуації випадковим чином генеруються за допомогою відповідних функцій LMS);

- додаткові завдання, результати виконання яких допомагають здійснити оцінку результатів навчання [7]. 


\section{ПЕДАГОГІЧНИЙ КОНТРОЛЬ В СИСТЕМІЦИФРОВОЇ ОСВІТИ}

Залежно від обраної дистанційної платформи для проведення екзамену, у викладачів може бути можливість надання здобувачам освіти права розпочинати складання іспиту в обраний ними час певного проміжку доби. Варто забезпечити однакову максимальну тривалість виконання завдань для всіх без винятку здобувачів освіти. При наявності творчого завдання максимальна тривалість екзамену може бути збільшена. Якщо під час іспиту виникнуть обставини непереборної сили, здобувач освіти повинен невідкладно попередити про це екзаменатора або ж відповідну особу. Для цього варто використовувати наявні канали зв'язку (телефон, месенджери тощо) 3 наданням фото- або ж відеофіксації стану виконання завдань, а також тих факторів, що об'єктивно не дають змоги продовжувати роботу 3 тих чи інших причин. У такому випадку можливість продовження або ж повторного складання екзамену визначається екзаменатором чи деканатом в індивідуальному порядку. Якщо допущені до іспиту здобувачі освіти мають об'єктивні причини, через які можуть виконувати завдання відповідно до визначеного розкладу із застосуванням передбачених технічних засобів, вони повинні надати матеріали, що підтверджують цей факт ще до початку екзаменаційного процесу. В такому випадку, розглянувши заяву, екзаменаційна комісія має ухвалити рішення, по якому надасть здобувачам освіти альтернативний спосіб здачі іспиту, що дозволяє здійснити, в тому числі, ідентифікацію особи з повним дотриманням рівня академічної доброчесності та можливістю повноцінної перевірки роботи. Серед основних варіантів альтернативної здачі екзамену варто виділити такі алгоритм дій: написання здобувачам освіти відповідей на поставленні питання від руки 3 подальшим їх фотографуванням або ж скануванням, а також надсилання роботи на перевірку екзаменаційній комісії наявними у нього технічними засобами комунікації. При умові, що повноцінне опанування навчальної дисципліни (або ж практика) потребує виконання завдань, котрі в дистанційному режимі розв'язати неможливо, відповідна дисципліна (практика) повинна бути перенесена на наступний навчальний семестр разом $з$ виконанням підсумкового оцінювання 3 неї. Для цього потрібно внести відповідні зміни до навчального плану здобувачів освіти. У такому випадку при виконанні розрахунку рейтингового бала здобувача освіти результати оцінювання конкретної дисципліни не будуть враховуватись у поточному семестрі. Вони вплинуть на цей процес у наступному навчальному періоді здобуття освіти.
Для проведення атестації у формі екзамену в дистанційному режимі вчена рада ЗВО повинна затвердити відповідну процедуру. Вона складається $з$ таких елементів:

- форма та порядок складання екзамену у дистанційному режимі за допомогою технічних засобів;

- організаційний порядок “хвиль” роботи екзаменаційної комісії з визначенням днів складання іспиту різними групами здобувачів освіти і можливостей повторного проведення екзамену $з$ тими здобувачами освіти, котрі не змогли скористатися першим варіантом через ті чи інші об' єктивні причини;

- дані про зміст і структурні особливості завдань, призначених для перевірки рівня знань здобувачів освіти;

- визначені критерії оцінювання результатів іспиту.

При опублікуванні списку екзаменаційних питань до проведення іспиту для нівелювання завчасної підготовки відповідей порядок проведення оцінювання може передбачати необхідність виконання одного додаткового завдання. Про це здобувачі освіти мають бути повідомленні безпосередньо під час іспиту. Мова йде, наприклад, про написання кодового слова в тексті роботи.

Атестаційний процес на першому та другому рівнях здобуття вищої освіти (бакалавраті та магістратурі відповідно) повинен виконуватися у формі захисту кваліфікаційних робіт здобувачів освіти за допомогою застосування засобів дистанційних технологій у синхронному режимі. Він передбачає використання відеоконференцій з обов'язковою цифровою фіксацією всього екзамену. До неї належать відео- або ж аудіозапис, фотографування або ж сканування робіт тощо.

Замість синхронного виступу альтернативою для здійснення захисту кваліфікаційних робіт може бути запис здобувачами освіти відеоматеріалу, направленого до екзаменаційної комісії у такий спосіб, щоб при його перегляді була можливість ідентифікації здобувача освіти та засвідчення факту його виступу. При цьому отримання запитань та надання відповідей обов'язково повинні здійснюватися у синхронному режимі.

Висновки та перспективи подальших досліджень. Здійснення педагогічного контролю за освітнім процесом у контексті здобуття освіти в дистанційному режимі - це досить важливий елемент освітнього процесу здобувачів освіти закладу вищої освіти. Перехід до цифрової форми навчання передбачає активність викладача як при наданні навчального матеріалу, так і при здійсненні 
оцінювання здобувачів освіти. Це стосується, в тому числі, і здобувачів освіти під час самостійного виконання ними завдань, метою яких є не тільки досягнення високих знань у професійній підготовці, але й отримання нових навичок, таких як самоконтроль. Для цього необхідно організовувати весь процес навчання та пізнавальної діяльності зробити його відмінним від стандартного.

Перспективність подальшого вивчення теми, що розглядається у статті, полягає у здійсненні додаткових досліджень і аналізу інноваційних підходів до контролю знань здобувачів освіти в дистанційному режимі навчання, а також огляду нормативно-правової бази, спрямованої на регулювання новітніх підходів до застосування цифрової освіти в Україні.

\section{ЛІТЕРАТУРА}

1. Безрученков Ю.В. Професійна освіта майбутніх фахівців готельно-ресторанного господарства в умовах дистанційного навчання. Проблеми інженерно-педагогічної освіти : зб. наук.пр. Укр. інж.-пед. акад.; голов. ред. д-р пед. наук, проф. Д.В. Коваленко. Харків, 2020, № 68. С. $69-80$.

2. Дмитренко Г., Помиткін Е., Головач Н. Формування здатних до самореалізації здобувачів освіти в умовах глобалізованого світу. Молодь $i$ ринок. Щомісячний науково-педагогічний журнал. Дрогобич, № 1(180) січень 2020. C.12-18.

3. Кузьмінський А.І. Педагогіка вищої школи. Навчальний посібник. А. І. Кузьмінський. Київ, 2005. 486 c.

4. Приходько В.В., Вікторов В.Г. Педагогічний контроль у вищій школі: Навчальний посібник /Заг. ред. і передмова В.В.Приходько. Дніпро: Національний гірничий університет, 2009. $150 \mathrm{c}$.

5. Романишина Л. М. Система поетапного контролю навчальної діяльності студентів за модульно-рейтинговою технологією навчання 3 дисциплін природничого циклу : дис. доктора пед. наук : 13.00.04. Київ, 1997. 417 с.

6. Фіцула М. Педагогіка вищої школи: навчальний посібник. Київ, 2006. 351 с.

7. Щодо організації поточного, семестрового контролю та атестації здобувачів освіти із застосуванням дистанційних технологій. Лист МОН № 1/9-249 від 14.05.20 року.

8. Ягупов В. В. Педагогіка: навч. посібник. Київ, 2002.560 с.

\section{REFERENCES}

1. Bezruchenkov, Yu.V. (2020). Profesiina osvita maibutnikh fakhivtsiv hotelno-restorannoho hospodarstva $v$ umovakh dystantsiinoho navchannia [Professional education of future specialists of hotel and restaurant industry in the conditions of distance learning]. Problems of engineering and pedagogical education: Coll. Scientific and Practical Ukr. eng.ped. acad. Kharkiv. No. 68.pp. 69-80. [in Ukrainian].

2. Dmytrenko, H., Pomytkin, E. \& Holovach, N. (2020). Formuvannia zdatnykh do samorealizatsii zdobuvachiv osvity v umovakh hlobalizovanoho svitu [Formation of self-fulfilling students in a globalized world]. "Youth and market". Monthly scientificpedagogical journal. Drogobych, Vol.1(180), pp. 12-18. [in Ukrainian].

3. Kuzminskyi, A.I. (2005). Pedahohika vyshchoyi shkoly [Pedagogy of high school]. Tutorial. A. I. Kuzminskyi. Kyiv. p. 486. [in Ukrainian].

4. Prykhodko, V.V. \& Viktorov, V.H. (2009). Pedahohichnyi kontroluvyshchii shkoli[Pedagogical control in high school]. Textbook. Dnipro, p. 150. [in Ukrainian].

5. Romanyshyna, L. M. (1997). Systema poetapnoho kontroliu navchalnoi diialnosti studentiv za modulno-reitynhovoiu tekhnolohiieiu navchannia z dystsyplin pryrodnychoho tsyklu [The system of stepby-step control of students' educational activity according to the modular-rating technology of teaching natural sciences]. Doctor's thesis. Kyiv, p. 417. [in Ukrainian].

6. Fitsula, M. (2006). Pedahohika vyshchoi shkoly: navchalnyi posibnyk [Pedagogy of higher school]. Textbook. Kyiv, p. 351. [in Ukrainian].

7. Shchodo orhanizatsiyi potochnoho, semestrovoho kontrolyu ta atestatsiyi zdobuvachiv osvity iz zastosuvannyam dystantsiynykh tekhnolohiy (2020). [Regarding the organization of current, semester control and certification of students with the use of distance technologies]. Letter of the Ministry of Education and Science No. 1/9-249 Kyiv, p.7. [in Ukrainian].

8. Yahupov, V. V. (2002). Pedahohika: navch. posibnyk [Pedagogy: Textbook. manual]. Kyiv, p. 560. [in Ukrainian].

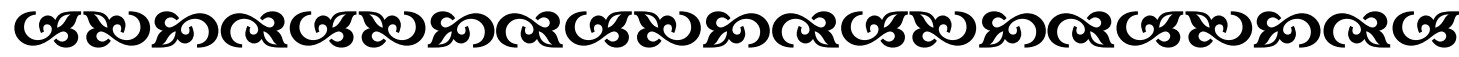

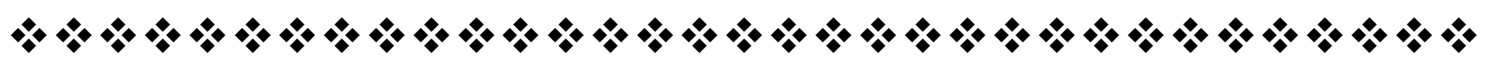

